\title{
Plankton studies in Buzzards Bay, Massachusetts, USA. III. Dinoflagellates, 1987 to 1988
}

\author{
Richard W. Pierce*, Jefferson T. Turner \\ Center for Marine Science and Technology, University of Massachusetts, Dartmouth, North Dartmouth, Massachusetts 02747, USA
}

\begin{abstract}
Dinoflagellates were counted and identified in $>20 \mu \mathrm{m}$ samples from Buzzards Bay, Massachusetts, USA, from October 1987 to September 1988. Eight stations were sampled at monthly or twice-monthly intervals. Dinoflagellates were the most abundant organisms in the $>20 \mu m$ microplankton samples (excluding diatoms), comprising up to $99 \%$ of total organisms. A total of 46 dinoflagellate species from 19 genera were recorded, and there were dinoflagellate blooms throughout the year. Bloom-forming taxa included Gymnodinium sanguineum, Heterocapsa triquetra, Prorocentrum minimum, and Prorocentrum triestinum. Mean annual dinoflagellate abundance was $9.7 \times 10^{3}$ cells $1^{-1}$,

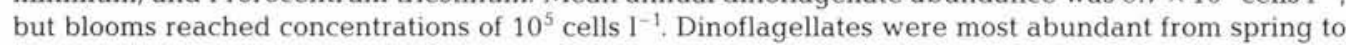
fall, and dinoflagellate blooms developed in between diatom blooms, coinciding with increasing silicate concentrations. This suggests that after silicate depletion by diatom blooms, dinoflagellates were able to exploit an undersaturated phytoplankton niche. Dinoflagellates were much more abundant at the New Bedford sewage outfall and in New Bedford Harbor than in the rest of the bay. The effect of concentrating dinoflagellate samples with a $20 \mu \mathrm{m}$ mesh screen was examined by comparisons of abundance of selected taxa in screened and unscreened whole-water samples concentrated by sedimentation. There were no significant differences between screened and whole-water samples (2-way ANOVA for paired comparisons) for total dinoflagellates, or for 5 abundant taxa.
\end{abstract}

KEY WORDS: Dinoflagellates · Buzzards Bay · Microplankton

\section{INTRODUCTION}

Dinoflagellates are conspicuous components of plankton assemblages, and various taxa may be trophically categorized as both 'phytoplankton' and/or 'microzooplankton' (Turner \& Roff 1993). Since many dinoflagellates are relatively large $(>20 \mu \mathrm{m})$, but occur in comparatively low numbers $\left(<10^{4}\right.$ cells $\left.1^{-1}\right)$, they may best be sampled separately from other phytoplankton. The reason is that a typical phytoplankton aliquot with acceptable counting error ( $>400$ cells; Guillard 1973), may be dominated, at least in coastal waters, by microflagellates and diatoms that occur at abundance levels of $10^{5}$ to $10^{6}$ cells $\mathrm{l}^{-1}$. Thus, important dinoflagellate species that are present at low abundance levels may remain unrecorded in the smallvolume aliquots (11 or less) typically examined for

\footnotetext{
- Present address: Graduate School of Oceanography, University of Rhode Island, Narragansett, Rhode Island 02882, USA
}

phytoplankton analyses. Many larger dinoflagellates are more accurately sampled along with other microplanktonic protists that occur at similarly low abundance levels. These organisms can be collected by screening several liters of seawater through $20 \mu \mathrm{m}$ mesh, realizing that smaller and fragile taxa may be lost.

Dinoflagellates are important components of the plankton in terms of food web interactions. Many dinoflagellates are autotrophic, but as many as half of extant species are heterotrophic or mixotrophic (Gaines \& Elbrächter 1984, Schnepf \& Elbrächter 1992). Heterotrophic dinoflagellates have recently been shown to be important consumers within microbial food webs (Jacobson \& Anderson 1986, Hansen 1991a, b, Lessard 1991, Strom \& Buskey 1993). It seems likely that thecate heterotrophic dinoflagellates compete with copepods for diatoms, while athecate heterotrophic dinoflagellates compete with ciliates for athecate pico- and nanoplankton (Lessard 1991). Some 
heterotrophic and mixotrophic dinoflagellates even prey on ciliates (Hansen 1991a, Bockstahler \& Coats 1993), thus reversing the previously expected trophic roles of ciliates and dinoflagellates. In addition, it has recently been found that some bloom-forming 'autotrophic' dinoflagellates are in fact mixotrophic (Bockstahler \& Coats 1993), and may be important predators on aloricate ciliates, especially in the $<20 \mu \mathrm{m}$ size fraction.

Many autotrophic dinoflagellates are also known to cause toxic, noxious or otherwise harmful blooms (Granéli et al. 1990, Smayda \& Shimizu 1993), and the apparent global epidemic of such blooms may partly relate to anthropogenic nutrient enrichment (Smayda 1989, 1990, 1991). Such blooms are important due to their large economic, human health, and environmental impacts, and much effort is currently being devoted to understanding mechanisms contributing to the formation and dispersal of harmful phytoplankton blooms (Smayda \& Shimizu 1993). While entire volumes have been written on large and spectacular dinoflagellate blooms, often exceeding $10^{6}$ cells $1^{-1}$, this study shows that dinoflagellate populations often show less dramatic blooms $\left(\geq 10^{3}\right.$ cells $\left.1^{-1}\right)$ over the course of their annual succession.

\section{METHODS AND MATERIALS}

Samples were collected at 8 stations in Buzzards Bay (Fig. 1). Stns $4,5 \& 6$ were in the central bay at depths of 10 to $15 \mathrm{~m}$. Stn 2 (depth $=8$ to $12 \mathrm{~m}$ ) was at the southwestern end of the Cape Cod Canal where strong currents (up to 4 knots) were caused by semidiurnal tidal flow either from Buzzards Bay to Cape Cod Bay, or the reverse. Accordingly, hydrographic conditions and plankton populations at Stn 2 were frequently different from elsewhere in Buzzards Bay, since the water sampled had originated from north of Cape Cod, long considered to be a major biogeographic boundary (Ekman 1953). Stns 1 \& 3 were in the shallow embayments of Mattapoisett and Megansett Harbors (depths $=5$ to $8 \mathrm{~m}$ ). Stn 7 (depth $=6$ to $8 \mathrm{~m}$ ) was over the subsurface outfall of the primary treatment sewage plant of the city of New Bedford. Stn 8 (depth $=8 \mathrm{~m}$ ) was in the inner harbor of New Bedford, behind a hurricane dike that restricts circulation with the rest of the bay. All stations were precisely located by Loran coordinates. Water column depths at a station varied with tidal range (1.0 to $1.5 \mathrm{~m}$ ). In order to complete sampling of the entire bay within the same day on each cruise, stations were sampled upon arrival irrespective of tidal state. All sampling was in daylight, usually between $07: 30$ and 15:00 h. Samples were collected between 1 October

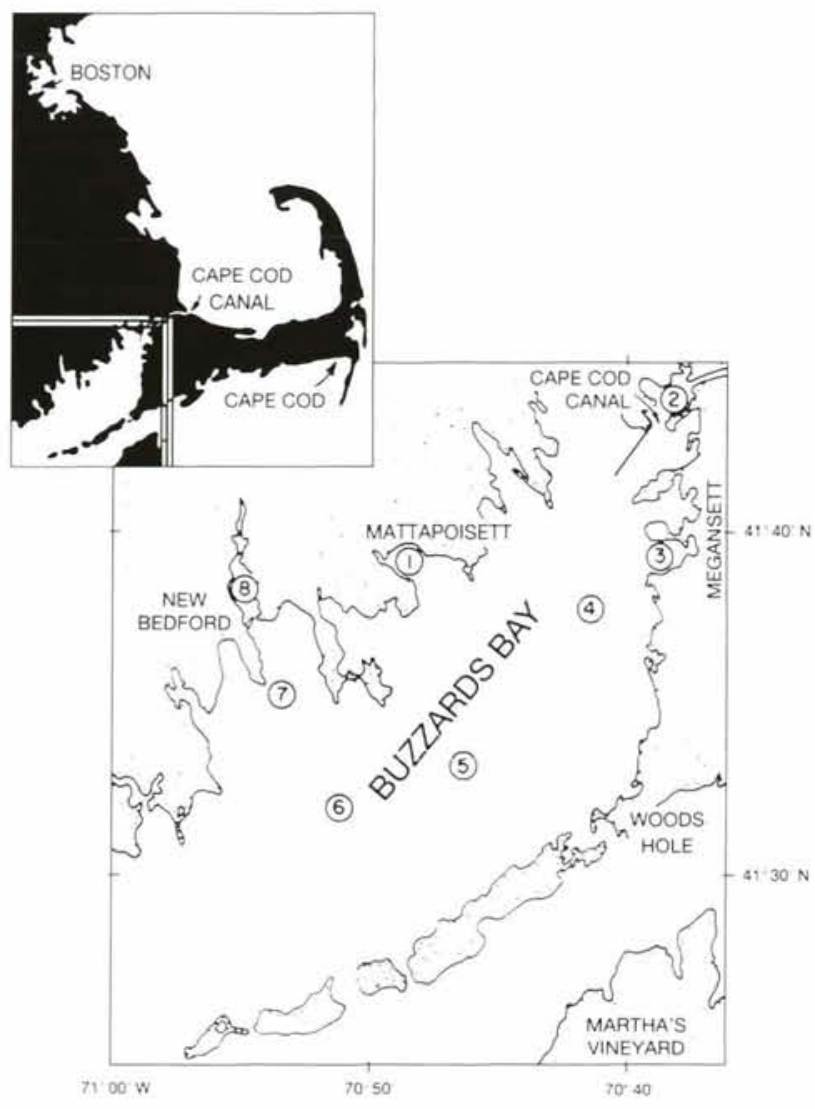

Fig. 1. Sampling stations in Buzzards Bay

1987 and 20 September 1988. Cruises were monthly except for biweekly cruises (twice each month) in October 1987, and June-September 1988.

Water samples were collected from just below the surface, with a Niskin bottle. Subsamples of 3 or 41 were concentrated with a $20 \mu \mathrm{m}$ mesh Nitex screen and preserved with $1 \%$ acid Utermöhl's solution (Guillard 1973). In the laboratory, microplankton samples were gravimetrically settled to aliquots of 50 to $150 \mathrm{ml}$. Subsamples were counted in a Sedgwick-Rafter cell with a phase contrast compound microscope. Samples were counted at $100 \times$ magnification, but the long working distance objectives on the microscope allowed specimens to be examined at up to $400 \times$ magnification when necessary for identification. Aliquots of 200 to 400 organisms were counted from each sample and identified to the lowest taxonomic level possible, usually species. Marshall (1986) and Campbell (1973) were the primary guides used for taxonomic decisions, although Dodge (1982) and Hulburt (1958) were also consulted.

Possible bias due to the use of a $20 \mu \mathrm{m}$ mesh for concentrating dinoflagellate samples was investigated by comparison of screened and sedimented whole-water samples. Both types of samples were taken from the 
same Niskin bottles and preserved with the same Utermöhl's solution; thus abundances of the same taxa should be similar in both sets of samples, unless there were effects associated with screening. In order to reduce counting error, 15 screened samples known to have high numbers of dinoflagellates were chosen for this comparison. These samples were counted to a total of at least 400 total dinoflagellate cells. While it was not possible to determine what loss, if any, resulted from preservation, it should have been consistent within sample pairs. For statistical analyses the comparison was considered to be a special case of randomized complete blocks design, thus a 2-way ANOVA for paired comparisons was done for each group (Sokal \& Rohlf 1981, p. 357)

\section{RESULTS}

Concentrating dinoflagellate samples with a $20 \mu \mathrm{m}$ mesh had no significant effect on the abundance estimates of total dinoflagellates, or of 5 individual dinoflagellate taxa examined. Taxa examined were Gymnodinium sanguineum, Heterocapsa triquetra, Prorocentrum micans, P. minimum, and P. triestinum. The latter 4 species are thecate, but the lack of any significant screening effect on the athecate G. sanguineum suggests that our screening technique did not cause substantial disruption of athecate taxa.

A total of 46 dinoflagellate species from 19 genera were observed in Buzzards Bay from October 1987 to September 1988. A complete species list has been previously published (Borkman et al. 1993). Sixteen dinoflagellate taxa occurred at abundances of at least
$10^{3}$ cells $1^{-1}$, representing the dominant dinoflagellates in Buzzards Bay (Table 1). Total dinoflagellate abundance ranged from $2.33 \times 10^{2}$ cells $1^{-1}$ to $2.27 \times 10^{5}$ cells $1^{-1}$, with a bay-wide mean of $9.70 \times 10^{3}$ cells $1^{-1}$. The annual bay-wide means of dinoflagellate abundance (Fig. 2) reveal that the stations at the New Bedford sewage outfall (Stn 7) and New Bedford Harbor (Stn 8) had a significantly higher dinoflagellate abundance than at all other stations.

Four dinoflagellates were important as 'bloom' species (Table 2). A bloom is defined here as $3.0 \times 10^{4}$ cells $1^{-1}$ or greater, (approximately 3 times the annual mean concentration of dinoflagellates). The bloom-forming species were Gymnodinium sanguineum, Heterocapsa triquetra, Prorocentrum minimum, and $P$. triestinum. Out of 8 samples that were collected from dinoflagellate blooms, 7 were collected in New Bedford Harbor (Stn 8), while the other was at the New Bedford sewage outfall ( $\operatorname{Stn} 7$ ).

In terms of distributional patterns of dinoflagellates, Buzzards Bay can be divided into 4 zones: Cape Cod Canal (Stn 2), Northern Bay (Stns 1, 3 \& 4), Mid-Bay (Stns $5 \& 6$ ), and New Bedford Harbor (Stns $7 \& 8$ ). These zones were chosen because of the geography of Buzzards Bay, and because the differences in the seasonal distributions of dinoflagellate taxa within these zones were less pronounced than differences between zones (Fig. 3).

\section{Cape Cod Canal}

The western end of the Cape Cod Canal (Stn 2) was marked by low numbers of dinoflagellates, but not sig-

Table 1. Dominant dinoflagellates in Buzzards Bay, October 1987 to September 1988. Maximum abundance at any station. Number is logarithm of the order of magnitude of species abundance in cells $1^{-1}$

\begin{tabular}{|c|c|c|c|c|c|c|c|c|c|c|c|c|c|c|c|c|c|}
\hline $\begin{array}{l}\text { Month: } \\
\text { Cruise no.: }\end{array}$ & $\begin{array}{c}\text { Oct } \\
1\end{array}$ & $\begin{array}{l}\text { Oct } \\
2\end{array}$ & $\begin{array}{c}\text { Nov } \\
3\end{array}$ & $\begin{array}{c}\text { Dec } \\
4\end{array}$ & $\begin{array}{c}\text { Jan } \\
5\end{array}$ & $\begin{array}{c}\text { Feb } \\
6\end{array}$ & $\underset{7}{\operatorname{Mar}}$ & $\begin{array}{l}\text { Apr } \\
8\end{array}$ & $\begin{array}{c}\text { May } \\
9\end{array}$ & $\begin{array}{c}\text { Jun } \\
10\end{array}$ & $\begin{array}{c}\text { Jun } \\
11\end{array}$ & $\begin{array}{l}\text { Jul } \\
12\end{array}$ & $\begin{array}{c}\text { Jul } \\
13\end{array}$ & $\begin{array}{c}\text { Aug } \\
14\end{array}$ & $\begin{array}{c}\text { Aug } \\
15\end{array}$ & $\begin{array}{l}\text { Sep } \\
16\end{array}$ & $\begin{array}{c}\text { Sep } \\
17\end{array}$ \\
\hline Alexandrium tamarense & 2 & 1 & & & & & 1 & & & 2 & 1 & 2 & 3 & 2 & 2 & 1 & 1 \\
\hline Ceratium lineatum & 3 & 2 & 2 & 2 & 2 & 1 & 1 & & & 2 & 3 & 3 & 2 & 2 & 2 & 2 & 2 \\
\hline C. minutum & & 1 & 1 & & & & & & & 2 & 2 & 3 & 1 & 2 & & & \\
\hline Dinophysis acuminata & 2 & 2 & 1 & 2 & 1 & 1 & 1 & 1 & 2 & 2 & 3 & 2 & 1 & 2 & 3 & 3 & 2 \\
\hline Gymnodinium sanguineum & 3 & 4 & 1 & & & & & & & & 1 & 2 & 2 & 2 & 1 & 1 & 1 \\
\hline Gyrodinium spirale & 2 & 2 & 2 & 1 & 1 & 1 & 2 & 1 & 2 & 2 & 3 & 1 & 1 & 2 & & 2 & 1 \\
\hline Unidentified gymnodinoids & 3 & 3 & 2 & 2 & 2 & 2 & 3 & 1 & 1 & 1 & 2 & 3 & 3 & 2 & 2 & 2 & 1 \\
\hline Heterocapsa triquetra & 3 & 3 & 3 & 2 & 2 & 3 & 4 & 5 & 5 & 3 & 2 & 2 & 3 & 3 & 1 & 1 & 1 \\
\hline Oblea rotunda & 3 & 2 & 2 & 2 & 1 & 2 & 2 & 1 & 1 & 2 & 2 & 3 & 3 & 3 & 2 & 2 & 1 \\
\hline Prorocentrum micans & 3 & 3 & 2 & 2 & 2 & 1 & 1 & 0 & 2 & 3 & 3 & 3 & 3 & 3 & 3 & 3 & 3 \\
\hline P. minimum & 3 & 2 & 2 & 2 & 1 & 1 & 1 & & & 2 & 2 & 3 & 4 & 4 & 3 & 1 & 1 \\
\hline P. triestinum & 3 & 3 & 1 & 0 & & & & & & 1 & 3 & 3 & 2 & 3 & 4 & 2 & 1 \\
\hline Protoperidinium claudicans & 2 & 1 & 1 & 1 & 1 & 1 & & & & 1 & & 2 & 3 & 3 & 2 & 2 & 1 \\
\hline$P$. pellucidum & 1 & 1 & 1 & 1 & 1 & 1 & 1 & 2 & 2 & 2 & 1 & 2 & 3 & 3 & 3 & 1 & 2 \\
\hline P. steinii & & 1 & 0 & 0 & 1 & 2 & 3 & 2 & 3 & 1 & 1 & 1 & 2 & 2 & & 1 & \\
\hline Scrippsiella trochoidea & 3 & 2 & 2 & 1 & 1 & 2 & 2 & 2 & 2 & 2 & 3 & 3 & 3 & 3 & 3 & 2 & 2 \\
\hline
\end{tabular}




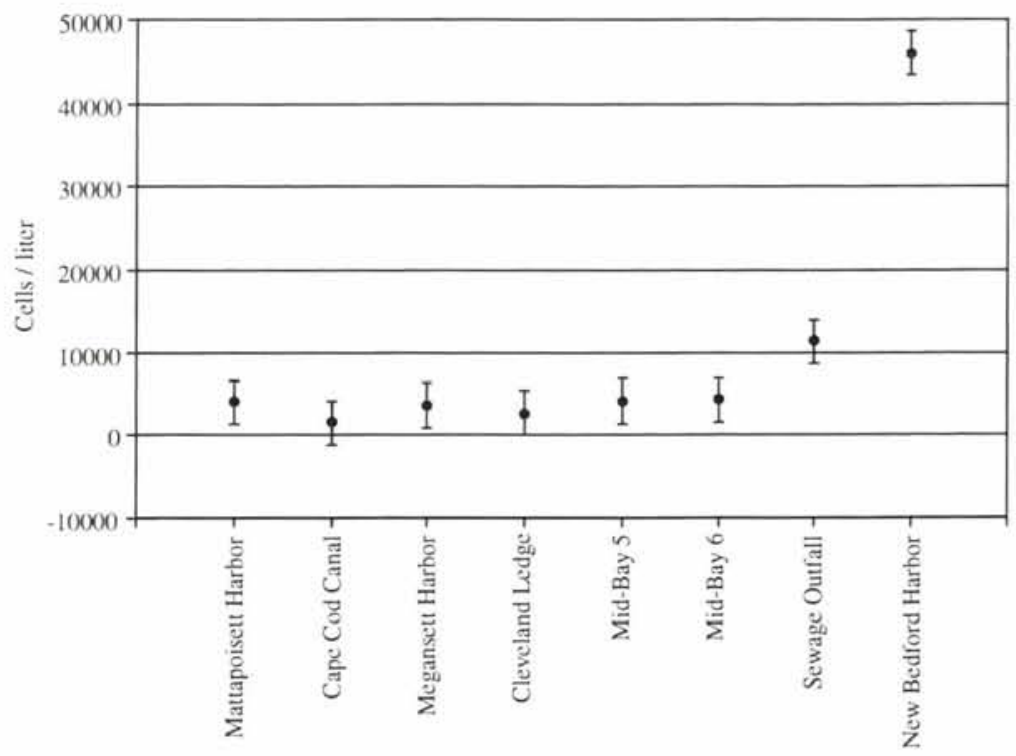

Fig. 2. Total annual mean dinoflagellate abundance (cells $1^{-1}$ ) at each station. Error bars are $95 \%$ comparison intervals. Means with error bars that do not overlap are significantly different (Sokal \& Rohlf 1981) and early fall. In general, Prorocentrum micans was abundant, with Prorocentrum triestinum also common in Mattapoisett Harbor (Stn 1). Dinoflagellate numbers were low throughout the winter, and did not show a large increase until June-July. This increase began first in the 2 harbors, and appeared to spread to Cleveland Ledge. Species composition shifted from Prorocentrum-dominated in the fall, to a mixed composition in the winter. Protoperidinium spp. and Heterocapsa triquetra dominated in April, especially Protoperidinium pellucidum and $P$. bipes. Dinoflagellate abundance increased throughout late spring and early summer, peaking in August. The August peak consisted mainly of $P$. micans and peridinians, most notably $P$. pellucidum and Scrippsiella trochoidea. Dinoflagellate abundance declined again in the fall.

\section{Mid-Bay}

mean a dingellate abundance at the Canal was only $1.56 \times 10^{3}$ cells $1^{-1}$, with maximum abundance of only $4.31 \times 10^{3}$ cells $\mathrm{I}^{-1}$. This maximum was at least an order of magnitude lower than the maximum at any other station. No distinct seasonal signal was detected at this station. The direction and duration of tidal flow did not correlate with abundance or species composition.

\section{Northern Zone}

Dinoflagellate distributions in Mattapoisett Harbor (Stn 1), Megansett Harbor (Stn 3), and Cleveland Ledge (Stn 4) showed a strong seasonal signal, with highest dinoflagellate abundance during late summer
Dinoflagellate abundances at Stns 5 \& 6 resembled the Northern Zone, but also showed the influence of New Bedford Harbor Zone. These Mid-Bay stations appeared to be a transition zone between the Northern Bay and New Bedford Harbor Zones. A notable difference from the Northern Zone included a decrease in the importance of peridinians, with a corresponding increase in Heterocapsa triquetra populations in April-May. There was also a dramatic drop in the abundance of dinoflagellates from 13 to 27 July, which was not observed in the Northern Bay. Dinoflagellate abundance remained low on 10 August, but rebounded almost completely by 23 August, before the autumn decline.

Table 2. Dinoflagellate blooms in Buzzards Bay. October 1987 to September 1988

\begin{tabular}{|c|c|c|c|c|c|}
\hline Date & Stn & Taxon & $\begin{array}{c}\% \text { of total } \\
\text { dinoflagellates }\end{array}$ & $\begin{array}{c}\text { No. of } \\
\text { dinoflagellates } \\
\left(\text { cells } 1^{-1}\right)\end{array}$ & $\begin{array}{l}\text { No. of } \\
\text { bloom taxa } \\
\left.\text { (cells } ~^{-1}\right)\end{array}$ \\
\hline 20 Oct 1987 & 8 & Gymnodinium sanguineum & 80 & 66800 & 53500 \\
\hline 1 Mar 1988 & 8 & Heterocapsa triquetra & 75 & 34400 & 25800 \\
\hline 5 Apr 1988 & 8 & Heterocapsa triquetra & 98 & 198900 & 195800 \\
\hline 3 May 1988 & 7 & Heterocapsa triquetra & 91 & 72700 & 66000 \\
\hline 3 May 1988 & 8 & Heterocapsa triquetra & 99 & 226800 & 223400 \\
\hline 27 Jul 1988 & 8 & Prorocentrum minium & 52 & 97600 & 50400 \\
\hline 10 Aug 1988 & 8 & Prorocentrum minium & 18 & 60000 & 10900 \\
\hline 23 Aug 1988 & 8 & Prorocentrum triestinum & 89 & 24700 & 22100 \\
\hline
\end{tabular}




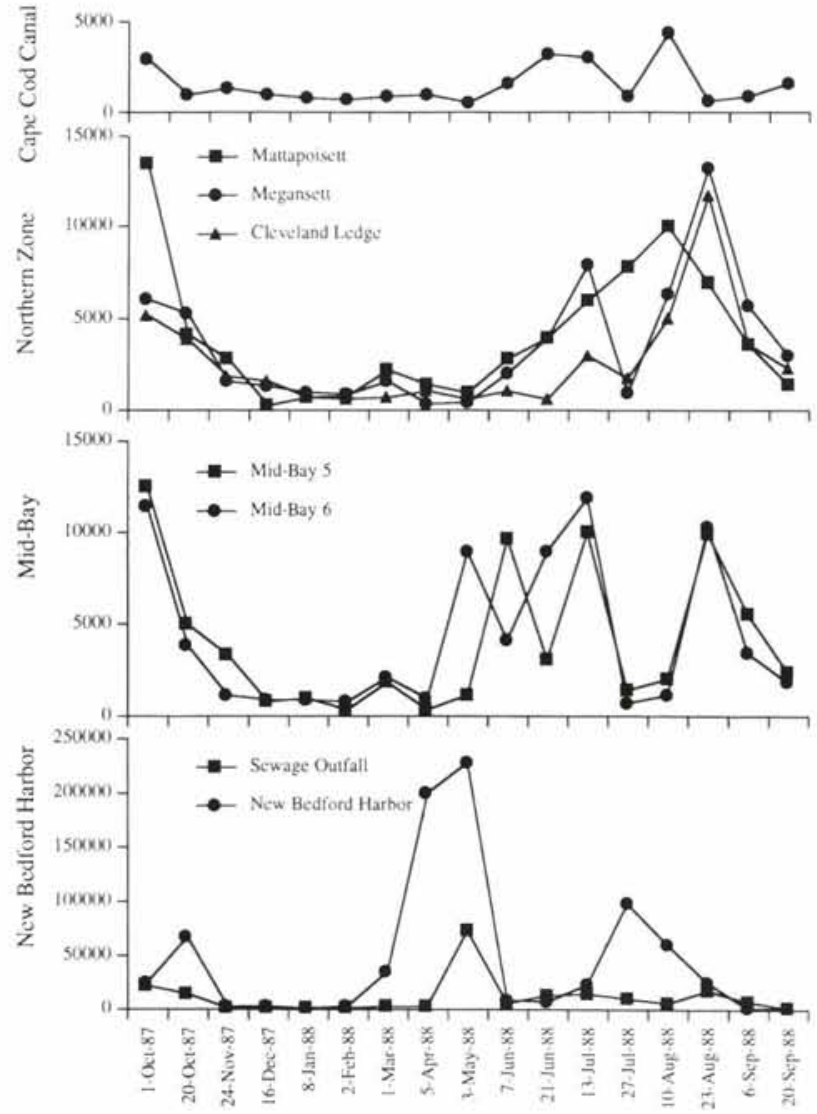

Fig. 3. Seasonal changes in total dinoflagellate abundance (cells $\mathrm{I}^{-1}$ ) by station and geographic area

\section{New Bedford Harbor}

The New Bedford Harbor Zone was characterized by significantly greater dinoflagellate abundances than elsewhere in Buzzards Bay (Fig. 2). Dinoflagellates were also significantly more abundant in New Bedford Harbor (Stn 8) than at the New Bedford sewage outfall (Stn 7). Table 2 shows that all dinoflagellate 'bloom' events in Buzzards Bay occurred in this zone, and although the New Bedford sewage outfall (Stn 7) and New Bedford Harbor (Stn 8) show significant differences in dinoflagellate abundance (Fig. 2), they are closely linked. The dinoflagellates at the New Bedford sewage outfall (Stn 7) were similar in terms of species composition to those of the Mid-Bay regions but were more abundant at the New Bedford sewage outfall than in the Mid-Bay and Northern Zones. The most notable event at Stn 7 was the large bloom of Heterocapsa triquetra present on 3 May.

Seven of the 17 samples taken in New Bedford Harbor (Stn 8) contained large numbers of dinoflagellates, comprising 3 major bloom events (Table 2). In October 1987, a bloom of Gymnodinium sanguineum occurred.
On 1 October, this dinoflagellate was present throughout the bay, with abundances of $10^{3}$ cells $1^{-1}$ in the Northern Zone and $10^{4}$ cells $1^{-1}$ at Stns $7 \& 8$. By 20 October, abundance of this species had increased to $5.4 \times 10^{4}$ cells $1^{-1}$ in New Bedford Harbor. G. sanguineum abundance remained high at the New Bedford sewage outfall, but decreased throughout the rest of the bay. G. sanguineum declined precipitously in November, and was absent from December until June of the following year. In 1988, G. sanguineum was present from June through September, but never exceeded abundances of $10^{3}$ cells $1^{-1}$.

The second bloom event occurred in spring of 1988 with Heterocapsa triquetra. This dinoflagellate was present year-round in Buzzards Bay, but its abundance fluctuated greatly (Fig. 4). H. triquetra was a major component of the dinoflagellate community in New Bedford Harbor (Stn 8) throughout the winter, but by 2 February, it had increased to $10^{3}$ cells $1^{-1}$, and continued to rise to $10^{4}$ cells $1^{-1}$ by March. This bloom then appeared along the north shore of the bay. $H$. triquetra peaked on 3 May with $2 \times 10^{5}$ cells $1^{-1}$ in New Bedford Harbor (Stn 8), $6.6 \times 10^{4}$ cells $1^{-1}$ at the New Bedford sewage outfall (Stn 7), and $7.8 \times 10^{3}$ cells $1^{-1}$ at Stn 6 . On 7 June, a small peak of $10^{3}$ cells $1^{-1}$ was observed at Mattapoisett Harbor (Stn 1) and Stn 5. H. triquetra numbers then decreased rapidly throughout the bay, experiencing a small rebound in Mattapoisett (Stn 1) and New Bedford Harbor (Stn 8) in late July and early August.

The third bloom was a midsummer bloom of Prorocentrum spp., especially P. minimum (Fig. 5), although high numbers of $P$. micans (Fig. 6) and $P$. triestinum (Fig. 7) were also recorded. Unlike the Heterocapsa triquetra bloom, which clearly originated in New Bed-

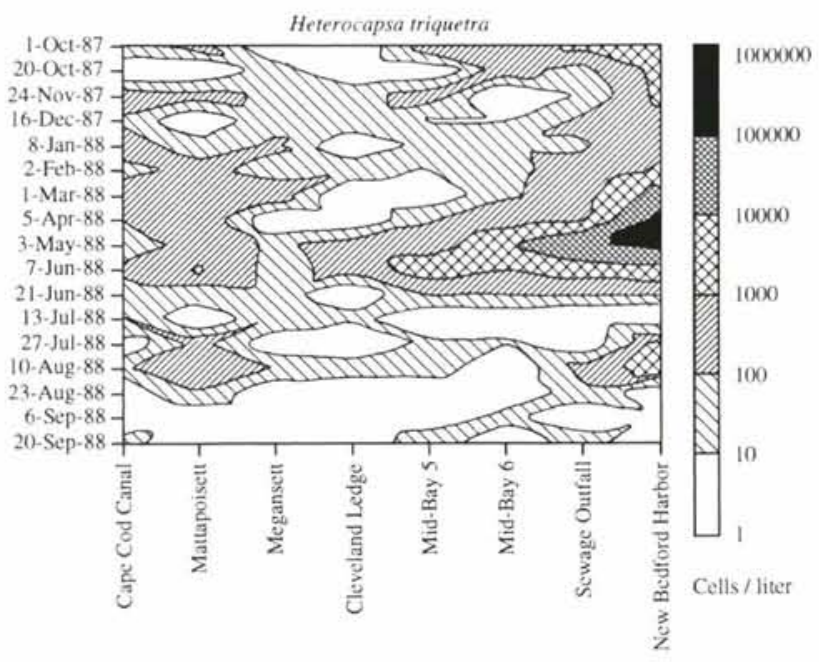

Fig. 4. Annual distribution of Heterocapsa triquetra 


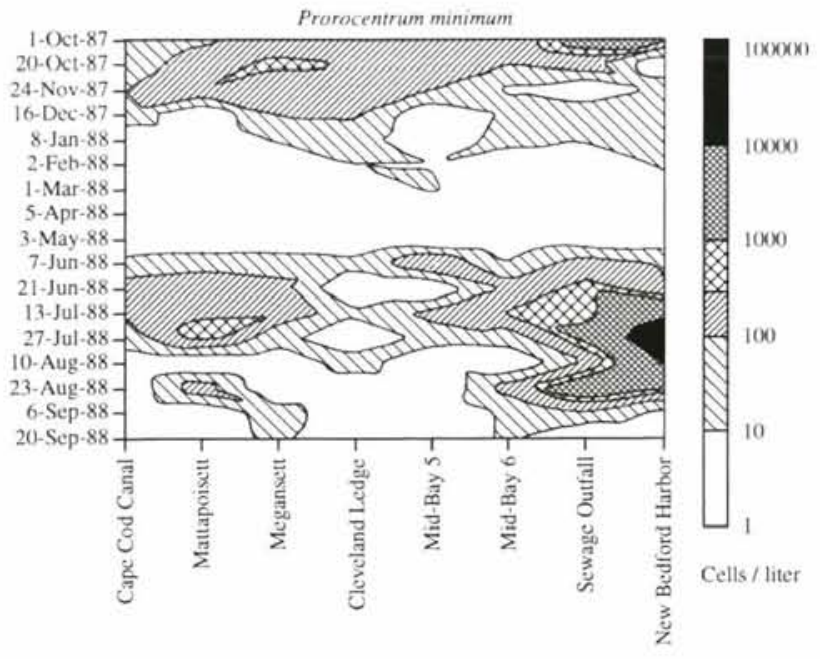

Fig. 5. Annual distribution of Prorocentrum minimum

ford Harbor (Stn 8), the Prorocentrum spp. bloom occurred simultaneously throughout the bay, although it was concentrated at the New Bedford sewage outfall (Stn 7) and New Bedford Harbor (Stn 8). The Prorocentrum bloom peaked in July-August, and declined in late August and September. The dominant species of the bloom also shifted from $P$. minimum in July and early August, to $P$. triestinum in late August.

Although not a 'bloom former' as defined here

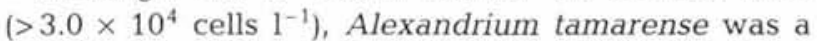
regular component of the plankton in Buzzards Bay from June to October (Fig. 8). A. tamarense was found at all stations, but was more typical of the northern zone (Stns 1, $3 \& 4$ ) and the Cape Cod Canal (Stn 2). Typical abundances for A. tamarense were $10^{1}$ to $10^{2}$ cells $1^{-1}$, but the one time it occurred in New Bedford Harbor (Stn 8), it exhibited $3 \times 10^{3}$ cells $1^{-1}$.

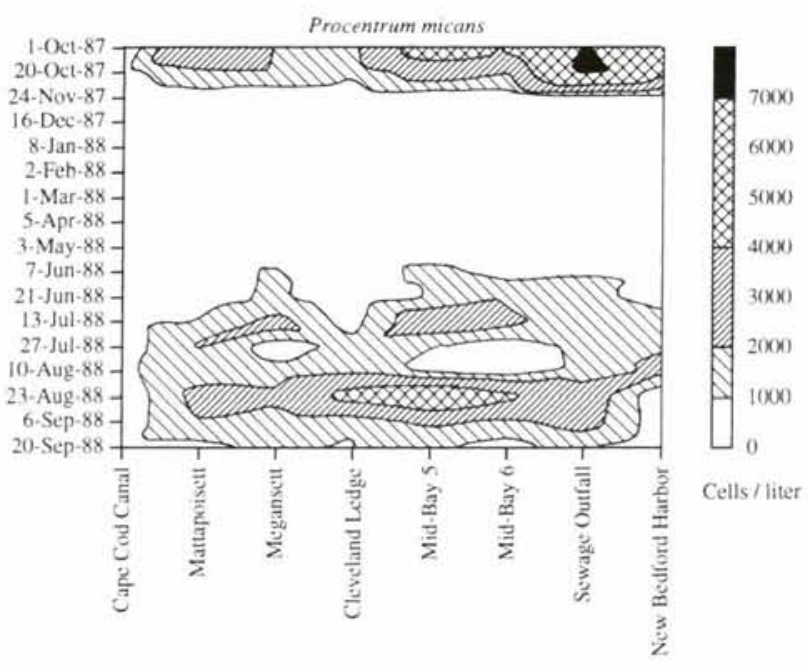

Fig. 6. Annual distribution of Prorocentrum micans

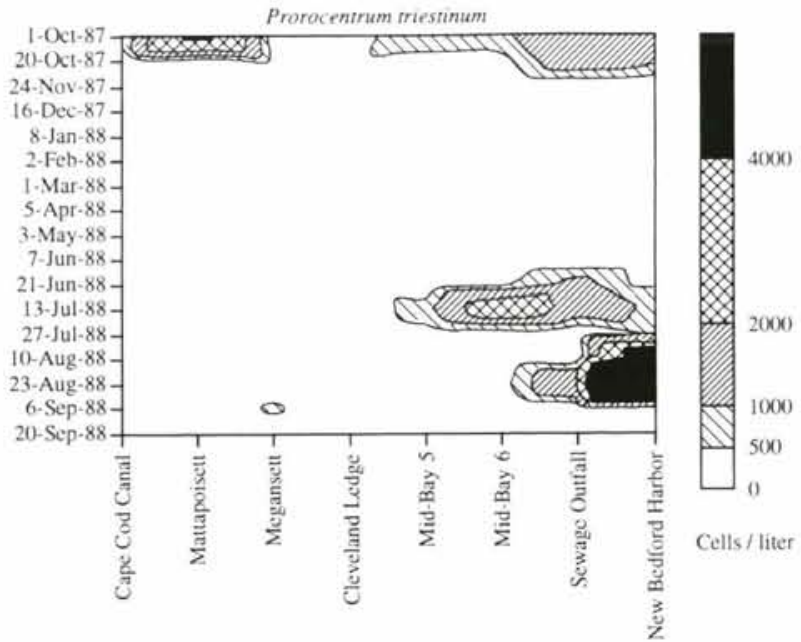

Fig. 7. Annual distribution of Prorocentrum triestinum

\section{DISCUSSION}

The dinoflagellate taxa observed in Buzzards Bay were typical neritic species for New England (Hulburt \& Rodman 1963). Most of the species found in Buzzards Bay have been reported by Marshall (1978, 1985) as widespread throughout east-coast United States coastal waters. A total of 46 species of dinoflagellates were recorded for Buzzards Bay, compared with 30 species from Narragansett Bay (Karentz \& Smayda 1984), and 80 species from Perch Pond near Woods Hole (Jacobson 1987).

The lack of an effect of screening with a $20 \mu \mathrm{m}$ mesh is important for this study, but needs to be interpreted with caution. Although none of the 5 taxa studied were found to be affected by screening, this cannot be interpreted to indicate that all dinoflagellates can be

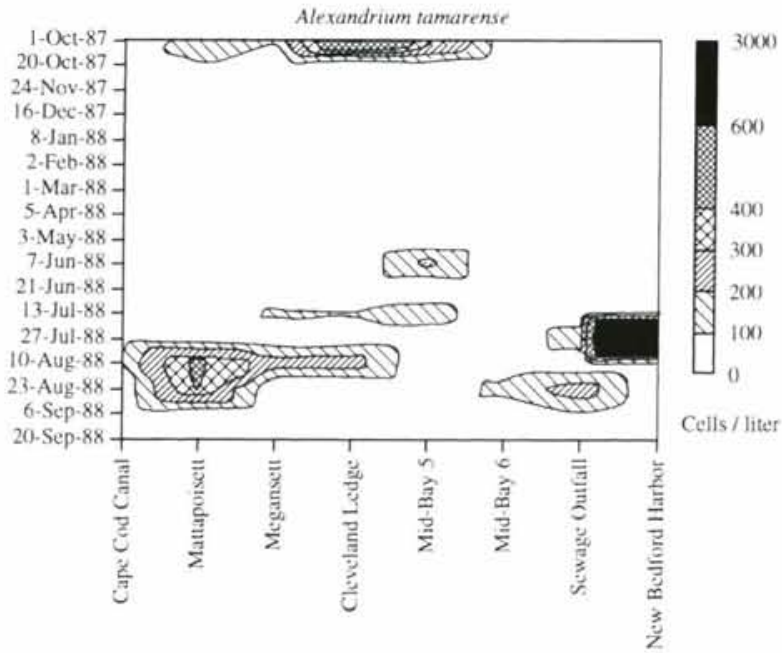

Fig. 8. Annual distribution of Alexandrium tamarense 
sampled this way. Some dinoflagellates are smaller than $20 \mu \mathrm{m}$, or may be too fragile to withstand screening. However, without screening, less abundant but important dinoflagellates may be missed. In this study the toxic dinoflagellate Alexandrium tamarense, which typically occurred in concentrations of 10 to 100 cells $1^{-1}$, would probably have been missed at most stations without screening. Thus screening with a $20 \mu \mathrm{m}$ mesh is important if larger and less abundant taxa are to be sampled adequately, provided that the limitations for smaller and fragile taxa are realized.

There was an apparent relationship between dinoflagellate abundance and silicate levels, but it was indirect (Borkman et al. 1993). Dinoflagellate dominance during late spring and early to mid-summer coincided with high levels of silicate. This was the period between diatom blooms in winter-early spring and late summer-early fall. It appears that dinoflagellates flourished as silicate stocks were being replenished after becoming depleted by the winter-spring diatom bloom. Both silicate concentrations and dinoflagellate abundance declined precipitously in late summer early fall, coincident with a major bloom of the diatom Skeletonema costatum (Borkman \& Turner 1993).

Although all the dinoflagellate blooms in Buzzards Bay were caused by photosynthetic dinoflagellates, at least one of these dinoflagellates is also a functional heterotroph. Gymnodinium sanguineum, which reached a peak abundance of 53500 cells $1^{-1}$, has been shown to be a predator of oligotrich ciliates $<20 \mu \mathrm{m}$ diameter in Chesapeake Bay (Bockstahler \& Coats 1993). In Chesapeake Bay up to $25 \%$ of G. sanguineum cells contained ingested ciliates when examined, so the predation impact from dinoflagellates might be an important factor in ciliate population dynamics. Heterotrophic activity is unknown for the other bloomforming dinoflagellates in Buzzards Bay, but other heterotrophic dinoflagellates also occurred in abundances of $10^{3}$ cells $1^{-1}$ at various times (Table 1 ). The recent discovery that several 'autotrophic' dinoflagellates are, in fact, mixotrophic (Bockstahler \& Coats 1993) complicates any meaningful attempt to partition the dinoflagellate community into heterotrophic and autotrophic components. It is also premature to attempt to calculate grazing impacts of mixotrophic and heterotrophic dinoflagellates, as we do not yet know grazing rates or under what conditions grazing becomes important. Based on the abundance of these dinoflagellates, however, it seems likely that heterotrophic dinoflagellates may have large impacts on the population dynamics of their prey items at certain times.

Although no toxic dinoflagellate blooms were recorded during the study period, several of the common dinoflagellate species in Buzzards Bay are known to cause toxic blooms in other areas. These dinoflagellates are: Alexandrium tamarense, Prorocentrum minimum, Dinophysis acuminata (Steidinger \& Baden 1984), and Prorocentrum micans (Cassie 1981). Gymnodinium sanguineum, which bloomed in the fall of 1987. has been shown to be avoided by zooplankton grazers off California (Fiedler 1982). Zooplankton avoidance may be one of the mechanisms contributing to the formation and persistence of dinoflagellate blooms (Fiedler 1982, Huntley 1982).

Alexandrium tamarense (formerly Gonyaulax tamarensis; see Moestrup \& Larsen 1990) is the best-known toxic dinoflagellate in New England waters (Anderson et al. 1982), and is responsible for recurrent red tides and shellfish bed closings from the Gulf of Maine to Cape Cod. A previous survey for $A$. tamarense cysts in Buzzards Bay only found cysts near Naushon Island, the largest of the Elizabeth Islands forming the southern boundary of the bay. Cysts are known to be a means by which $A$. tamarense blooms are initiated and maintained in an area from year to year (Anderson et al. 1983). The present study reveals $A$. tamarense to be widespread in Buzzards Bay during the warmer months, and as abundant as $3 \times 10^{3}$ cells $1^{-1}$ in New Bedford Harbor (Stn 8). It is not known if this abundance level resulted in shellfish toxicity, since New Bedford Harbor and many of the nearby areas are perpetually closed to shellfishing due to contamination by fecal coliforms or other pollutants.

The distribution of Alexandrium tamarense in Buzzards Bay (Fig. 8) suggests 2 of the factors influencing the dinoflagellate distributions in Buzzards Bay. When A. tamarense was present in Buzzards Bay, it was usually present at the Cape Cod Canal, suggesting that many of these cells may be introduced from Massachusetts Bay and the Gulf of Maine through the Cape Cod Canal. The one time A. tamarense was observed in New Bedford Harbor it was in unusually high numbers, supporting the idea that the harbor may serve as an incubator for dinoflagellate blooms. A. tamarense is known to use vertical migration to enhance its retention in estuaries (Anderson \& Stolzenbach 1985), and this would likely be effective in New Bedford Harbor.

The 3 Prorocentrum species present in Buzzards Bay are common dinoflagellates, not only in New England coastal waters, but present year-round along the entire continental shelf of the northeastern United States (Marshall 1984, Marshall \& Cohn 1987). Blooms of Prorocentrum are not uncommon, and appear to be concentrated in nearshore regions (Marshall 1984). $P$. micans, $P$. minimum, and $P$. triestinum have also been reported as common bloom-forming dinoflagellates in nearby Narragansett Bay (Smayda 1959, Furnas 1983, Karentz \& Smayda 1984). 
In Buzzards Bay, Prorocentrum appears to be absent, or present in low numbers in the winter, although it can be common any time the rest of the year. In October $1987, P$. micans was abundant at the New Bedford sewage outfall (Stn 7), but it never became abundant in New Bedford Harbor (Stn 8). This was notably different from the distributions of $P$. minimum and $P$. triestinum. Both of these smaller dinoflagellates bloomed in New Bedford Harbor (Stn 8). P. minimum bloomed first, and peaked on 27 July with $5 \times 10^{4}$ cells $1^{-1}$. P. minimum was still abundant at the New Bedford sewage outfall (Stn 7) 1 mo later when $P$. triestinum bloomed to $2.2 \times 10^{4}$ cells $1^{-1}$ in New Bedford Harbor (Stn 8). These 2 species appeared to be important components of a succession of blooms that took place in New Bedford Harbor. Unfortunately we lack the data to determine whether the blooms occurred due to a native seed population present in New Bedford Harbor which bloomed under appropriate conditions, or if currents and winds brought seed or bloom populations into New Bedford Harbor from offshore. If there is a native seed population, then blooms are likely to be an annual event, as in Chesapeake Bay (Tyler \& Seliger 1978). Lacking a seed population, the blooms may be more sporadic, depending on weather and wind conditions.

Heterocapsa triquetra was an important bloomforming dinoflagellate in spring in Buzzards Bay, as in other locations along the east coast of the United States (Sellner \& Olson 1985, Tyler 1986). H. triquetra was the only dinoflagellate to exceed densities of $10^{4}$ cells $\mathrm{I}^{-1}$ in the 1987 to 1988 samples. The spring $H$. triquetra bloom began in New Bedford Harbor (Stn 8), and appeared to spread out from there, possibly aided by physical transport by wind, tide, or runoff from spring rains. The role of physical transport of dinoflagellate blooms by winds, currents, and river plumes is becoming increasingly appreciated (Tyler \& Seliger 1978, Tester et al. 1989, 1991, Franks \& Anderson 1992a, b).

New Bedford Harbor (Stn 8) and the New Bedford sewage outfall (Stn 7) are clearly different from the rest of Buzzards Bay, unquestionably due to human influence. The hurricane barrier reduces circulation with the rest of the bay and may encourage temperature stratification, especially on calm, sunny days (Turner \& Borkman 1993). The New Bedford sewage outfall contributes nutrients such as ammonium, nitrate and orthophosphate, enriching the New Bedford Harbor Zone (Borkman \& Turner 1993). These conditions appear to encourage the growth of dinoflagellates, especially when diatoms may be limited by silica depletion (Borkman et al. 1993). It should be noted that this system has the potential to produce toxic dinoflagellate blooms with Alexandrium tamarense and other potentially noxious taxa present throughout much of the year.
The distribution of Heterocapsa triquetra following the spring 1988 bloom suggests that blooms which develop in New Bedford Harbor (Stn 8) could spread at least as far as Mattapoisett Harbor (Stn 1). The fact that all dinoflagellate blooms appeared to start from New Bedford Harbor, the part of Buzzards Bay most heavily impacted by human activities, supports the hypothesis that the recent epidemic of blooms can be partly related to anthropogenic influence (Smayda 1989, 1990 , 1991)

Both Megansett Harbor (Stn 3) and Mattapoisett Harbor (Stn 1) also showed slightly elevated dinoflagellate abundances, although they never reached the levels of New Bedford Harbor (Stn 8). These embayments are shallower than the open part of the bay, and probably receive some extra nutrients from land runoff and other non-point sources. They were not as restricted in circulation as New Bedford Harbor (Stn 8), however, thus the formation of dinoflagellate blooms appears less likely.

The Cape Cod Canal had an effect on both abundance and species composition of dinoflagellates. Dinoflagellate abundance at the Cape Cod Canal (Stn 2) was typically the lowest in the bay on any given day. The best indicator of the effect the canal had on species composition was for the increased occurrence of Alexandrium tamarense here. Although dinoflagellates may be transported through the Canal, this was not clearly correlated with tides on the day of collection.

It is still unclear what factors are responsible for the fluctuations of dinoflagellate populations in Buzzards Bay, but there does appear to be a seasonal signal that varies throughout the bay. While dinoflagellate blooms of such magnitude as to discolor the water are the most noticeable aspect of dinoflagellate community dynamics, there are many less spectacular blooms which occur as part of the normal seasonal succession of dinoflagellates. These normal blooms may not have the obvious impact of toxic blooms, but their influences on food web dynamics may still be far reaching, especially in view of the increasingly appreciated central role that dinoflagellates play in the microbial food web.

\section{LITERATURE CITED}

Anderson, D. M., Kulis, D. M., Orphanos, J. A., Ceurvels, A. R. (1982). Distribution of the toxic dinoflagellate Gonyaulax tamarensis in the southern New England region. Estuar. coast. Shelf Sci. 14: 447-458

Anderson, D. M., Chisolm, S. W., Watras, C. J. (1983). The importance of life cycle events in the population dynamics of Gonyaulax tamarensis. Mar. Biol, 76: 179-189

Anderson, D. M., Stolzenbach, K. D. (1985). Selective retention of two dinoflagellates in a well-mixed estuarine embayment: the importance of diel vertical migration and surface avoidance. Mar. Ecol. Prog. Ser. 25:39-50 
Bockstahler, K. R., Coats, D. W. (1993). Spatial and temporal aspects of mixotrophy in Chesapeake Bay dinoflagellates. J. Eukaryot. Microbiol 40: 49-60

Borkman, D. G., Turner, J. T. (1993). Plankton studies in Buzzards Bay, Massachusetts, USA. II. Nutrients, chlorophyll $a$ and phaeopigments, 1987 to 1990. Mar. Ecol. Prog. Ser. 100: $27-34$

Borkman, D. G., Pierce, R. W., Turner, J. T. (1993). Dinoflagellate blooms in Buzzards Bay, Massachusetts. In Smayda, T. J., Shimizu, Y (eds.) Toxic phytoplankton blooms in the sea. Elsevier, Amsterdam, p. 211-216

Campbell, P. H. (1973). Studies on brackish water phytoplankton. Univ. of North Carolina Sea Grant Publication UNC-SG-73-07

Cassie, V. (1981). Non-toxic blooms of Prorocentrum micans (Dinophyceae) in the Karamea Bight. N.Z. J. mar. Freshwat. Res. 15: 181-184

Dodge, J. D. (1982). Marine dinoflagellates of the British Isles. Her Majesty's Stationery Office, London

Ekman, S. (1953). Zoogeography of the sea. Sidgwick and Jackson, London

Fiedler, P. C. (1982). Zooplankton avoidance and reduced grazing responses to Gymnodinium splendens (Dinophyceae). Limnol. Oceanogr. 27: 961-965

Franks, P. J. S., Anderson, D. M. (1992a). Alongshore transport of a toxic phytoplankton bloom in a buoyancy current: Alexandrium tamarense in the Gulf of Maine. Mar. Biol 112: $153-164$

Franks, P. J. S., Anderson, D. M. (1992b). Toxic phytoplankton blooms in the southwestern Gulf of Maine: testing hypotheses of physical control using historical data. Mar. Biol. 112: $165-174$

Furnas, M. J. (1983). Community structure, biomass and productivity of size-fractionated summer phytoplankton populations in lower Narragansett Bay, Rhode Island J. Plankton Res. 5: 637-655

Gaines, G., Elbrächter, M. (1984). Heterotrophic nutrition. In: Taylor, F. J. R. (ed.) The biology of dinoflagellates. Blackwell, Oxford, p. 224-268

Granéli, E., Sundstrom, B., Edler, L., Anderson, D. M. (eds.) (1990). Toxic marine phytoplankton. Elsevier, Amsterdam

Guillard, R. R. L. (1973). Division rates. In: Stein, J. R. (ed.) Handbook of phycological methods. Cambridge University Press, Cambridge, p. 289-311

Hansen, P. J. (1991a). Dinophysis - a planktonic dinoflagellate genus which can act both as a prey and a predator of a ciliate. Mar. Ecol. Prog. Ser. 69: 201-204

Hansen, P. J. (1991b). Quantitative importance and trophic role of heterotrophic dinoflagellates in a coastal pelagial food web. Mar. Ecol. Prog. Ser. 73: 253-261

Hulburt, E. M. (1958). The taxonomy of unarmored Dinophyceae of shallow embayments of Cape Cod, Massachusetts. Biol. Bull. 112: 196-219

Hulburt, E. M., Rodman, J. (1963). Distribution of phytoplankton species with respect to salinity between the coast of southern New England and Bermuda. Limnol. Oceanogr. 8: 263-369

Huntley, M. E. (1982). Yellow water in La Jolla Bay, California, July 1980. II. Suppression of zooplankton grazing. J. exp. mar. Biol. Ecol. 63: 81-91

Jacobson, D. M., Anderson, D. M. (1986). Thecate heterotrophic dinoflagellates: feeding behavior and mechanisms. J. Phycol. 22: 249 258

Jacobson, D. M. (1987). The ecology and feeding biology of thecate heterotrophic dinoflagellates. Ph.D. dissertation, Woods Hole Oceanographic Institution/Massachusetts Institute of Technology Joint Program in Oceanography and Oceanographic Engineering

Karentz, D., Smayda, T. J. (1984). Temperature and seasonal occurrence patterns of 30 dominant phytoplankton species in Narragansett Bay over a 22-year period (1959-1980). Mar. Ecol. Prog. Ser. 18: 277-293

Lessard, E. J. (1991). The trophic role of heterotrophic dinoflagellates in diverse marine environments. Mar. microb. Food Webs 5: 49-58

Marshall, H. G. (1978). Phytoplankton distribution along the eastern coast of the USA. Part II. Seasonal assemblages north of Cape Hatteras, North Carolina. Mar. Biol. 45: 203-208

Marshall, H. G. (1984). Phytoplankton distribution along the eastern coast of the U.S.A. Part V. Seasonal density and cell volume patterns for the northeastern continental shelf. J. Plankton Res. 6: 169-193

Marshall, H. G. (1985). Comparison of phytoplankton concentrations and cell volume measurements from the continental shelf off Cape Cod, Massachusetts, U.S.A. Hydrobiologia 120: 171-179

Marshall, H. G. (1986). Identification manual for phytoplankton of the United States Atlantic coast. U.S. Environmental Protection Agency, EPA/600/4-86/003

Marshall, H. G., Cohn, M. S. (1987). Phytoplankton composition of the New York Bight and adjacent waters. J. Plankton Res. 9: 267-276

Moestrup, O., Larsen, J. (1990). Some comments on the use of the generic names Ptychodiscus and Alexandrium. In: Granéli, E., Sundstrom, B., Elder, L., Anderson, D. M. (eds.) Toxic marine phytoplankton. Elsevier, Amsterdam, p. $78-81$

Schnepf, E., Elbrächter, M. (1992). Nutritional strategies in dinoflagellates. A review with emphasis on cell biological aspects. Eur. J. Protistol. 28: 3-24

Sellner, K. G., Olson, M. M. (1985). Copepod grazing in red tides of Chesapeake Bay. In: Anderson, D. M. White, A. W., Baden, D. G. (eds.) Toxic dinoflagellates. Elsevier, Amsterdam, p. 245-250

Smayda, T. J. (1959). Phytoplankton studies in lower Narragansett Bay. Limnol. Oceanogr. 4: 342-359

Smayda, T. J. (1989). Primary production and the global epidemic of phytoplankton blooms in the sea: a linkage? In: Cosper, E. M., Bricelj, V. M., Carpenter, E. J. (eds.) Novel phytoplankton blooms. Causes and impacts of recurrent brown tides and other unusual blooms. Coastal and Estuarine Studies 35. Springer-Verlag, Berlin, p. $449-483$

Smayda, T J. (1990). Novel and nuisance phytoplankton blooms in the sea: evidence for a global epidemic. In: Granéli, E., Sundstrom, B., Elder, L., Anderson, D. M. (eds.) Toxic marine phytoplankton. Elsevier, Amsterdam, p. $29-40$

Smayda, T J. (1991). Global epidemic of noxious phytoplankton blooms and food chain consequences in large ecosystems. In: Sherman, K., Alexander, L. M., Gold, B. D. (eds.) Food chains, yields, models, and management of large marine ecosystems. Westview Press, Boulder, p. $275-307$

Smayda, T. J., Shimizu, Y. (eds.) (1993). Toxic phytoplankton blooms in the sea. Elsevier, Amsterdam

Sokal, R. R., Rohlf, F. J. (1981). Biometry, 2nd edn. W. H. Freeman and Company, New York

Steidinger, K. A., Baden, D. G. (1984). Toxic marine dinoflagellates. In: Spector, D. L. (ed.) Dinoflagellates. Academic Press, New York, p. 201-261

Strom, S. L., Buskey, E. J. (1993). Feeding, growth, and behavior of the thecate heterotrophic dinoflagellate Oblea 
rotunda. Limnol. Oceanogr. 38: 965-977

Tester, P. A., Fowler, P. K., Turner, J. T (1989). Gulf Stream transport of the toxic red tide dinoflagellate Ptychodiscus brevis from Florida to North Carolina. In: Cosper, E. M. Bricelj, V. M., Carpenter, E. J. (eds.) Novel phytoplankton blooms. Causes and impacts of recurrent brown tides and other unusual blooms. Coastal and Estuarine Studies 35 Springer-Verlag, Berlin, p. 349-358

Tester, P. A., Stumpf, R. P., Vukovich, F. M., Fowler, P. K. Turner, J. T (1991). An expatriate red tide bloom: transport, distribution, and persistence. Limnol. Oceanogr. 36: 1053-1061

Turner, J. T., Borkman, D. G. (1993). Plankton studies in Buzzards Bay, Massachusetts, USA. 1. Hydrography and

This article was presented by D. A. Caron (Senior Editorial Advisor), Woods Hole, Massachusetts, USA bacterioplankton, 1987 to 1990. Mar. Ecol. Prog. Ser 100: $17-26$

Turner, J T., Roff, J. C. (1993). Trophic levels and trophospecies in marine plankton: lessons from the microbial food web. Mar. microb. Food Webs 7: 225-248

Tyler, M. A. (1986). Flow-induced variation in transport and deposition pathways in the Chesapeake Bay: the effect on phytoplankton dominance and anoxia. In: Wolfe, D. A. (ed.) Estuarine variability. Academic Press, New York, p. $161-175$

Tyler, M. A., Seliger, H. H. (1978). Annual subsurface transport of a red tide dinoflagellate to its bloom area: water circulation patterns and the organism distributions in the Chesapeake Bay. Limnol. Oceanogr. 23: 227-246

Manuscript first received: January 22, 1993

Revised version accepted: May 17, 1994 